\title{
Analysis of Climate Change and Rural Farmers' Perception in North Central Nigeria
}

\author{
A. A. Falaki ${ }^{1}$, J.A. Akangbe ${ }^{1}$ and O. E. Ayinde ${ }^{2^{*}}$ \\ ${ }^{1}$ Department of Agricultural Extension and Rural Development, \\ University of Ilorin, Ilorin, Nigeria \\ ${ }^{2}$ Department of Agricultural Economics and Farm Management, \\ University of Ilorin, Ilorin, Nigeria \\ Telephone: +2348038309935; E-mail: opeayinde@yahoo.com
}

KEYWORDS Adaptation. Climate Change. Farmers. Perception

\begin{abstract}
The perception of climate change as a hazard will influence people's response to it. This study examined farmers' perception of temperature and rainfall between 1980 and 2009, and how age, sex, education and household size correlated with climate change perception. Simple random sampling with proportionate representation was used to determine sample size (411) from a sampling frame of 6000 farmers. Structured questionnaire was used for data collection and this was supplemented with interview of key informants. Temperature and rainfall records of Makurdi Meteorological Station were used as proxy for the study area. Data were analysed using regression and Pearson Product Moment Correlation. Results showed an increasing trend in temperature and rainfall amount, rainfall unpredictability, corroborated by majority of the farmers' perception. Bush burning, tree cutting and sinful behaviour were ranked as leading causes of climate change. Sex was significantly related to climate change perception and adaptation. Age, sex education and household size had significant impacts on the farmers' perception of climate change effect on social, biological and eco-system functions. In conclusion, rural farmers correctly perceived the changes in the climate. It was recommended that demographic attributes of farmers and farming communities should be incorporated into climate change awareness and adaptation policies.
\end{abstract}

\section{INTRODUCTION}

\section{Background to the Study}

Agriculture is one of the sectors most vulnerable to climate change impact in Africa (Falaki et al. 2012). Impact of climate is observed more where agriculture is rain-fed and essential for the daily subsistence such in Nigeria. Across Nigeria, millions of people are already experiencing changing seasonal patterns of rainfall and increased heat. There are projections of increases in rainfall in the humid regions of southern Nigeria, which are accompanied by increases in cloudiness and rainfall intensity particularly during severe storms. Similarly, the savannah areas of northern Nigeria were projected to experience less rainfall, which coupled with temperature increases, reduces soil moisture availability Ogbo et al. (2013). The country's coastline (about $853 \mathrm{~km}$ long) makes the large population of coastal communities vulnerable to increases in sea level and storm surges. Almost two-third of Nigeria's land cover is prone to

*Address correspondence to

Dr. O. E. Ayinde drought and desertification. Climate therefore determines to a large extent availability of water, which impacts health and ultimately the level of poverty amongst Nigerians.

The country's high population of over 150 million people depend primarily on their physical environment for food, livelihoods and survival. Unfortunately, Nigeria lacks the financial capacity and technological resources to address the postulated negative impacts of current and predicted climate change and has not yet fully established an institutional and legal framework, systematic approach or policies targeted mitigating and adapting to the impacts of climate change. Given the above factors, it is clear that Nigeria's long-term development goal of poverty reduction and economic growth will be severely constrained if insufficient attention is paid to the issue of climate change in Nigeria.

According to Ajayi (2009), of Nigeria's $923,768 \mathrm{~km}^{2}, 34 \%$ is occupied by crops, $23 \%$ by grassland and $16 \%$ forests. Approximately $13 \%$ is rivers, lakes and reservoirs, and the remaining $14 \%$ fall under other uses. Small-scale farm holdings predominate in Nigeria, accounting for about $94 \%$ of the agricultural output (Ajayi 2009). Agriculture employs over $70 \%$ of the population, contributes about $41 \%$ of GDP, ac- 
counts for $5 \%$ of total export and provides $88 \%$ of non-oil earnings.

The Intergovernmental Panel on Climate Change (IPCC) fourth assessment report indicated that smallholder and subsistent farmers, pastoralists and artisan fisher folk will suffer complex, localised impacts of climate change (Boko et al. 2007). They face an increasingly complex set of challenges that make them more vulnerable than ever to changes that are beyond their control.

The Strengthening the Livelihoods of Small Scale Farmers in Nigeria (SLISSFAN) project co-financed by Oxfam GB and the European Commission is a model in agricultural development program. Oxfam GB is a development, relief and campaigning organisation that work with others to find lasting solutions to poverty and suffering around the world. The SLISSFAN project has the specific objective of improving the livelihoods of 6,000 poor rural households in small communities in Benue, Nasarawa and Plateau States of North Central Nigeria, with women comprising 60 percent of target beneficiaries. The project operated between 2008 and 2011.

While the SLISSFAN project has no climate change component, feedbacks from farmers engaged in the project and from partner organisations working with Oxfam GB in these communities indicated that climate change is impacting negatively on the farming operations and livelihoods of the small scale farmers they are working with thereby creating challenges not planned. This study is focussed on the SLISSFAN project communities in North Central Nigeria.

\section{Objectives of the Study}

The broad objective of this study is to examine the demographic determinants of farmers' perception and adaptation to climate change in North Central Nigeria. The specific objectives are to; (i) compare farmers' perception of temperature and rainfall with meteorological records and (ii) investigate how age, sex, education and household size correlate with perception and adaptation to climate change.

\section{Theoretical Background to Climate Change Perception and Adaptation}

In agriculture, adaptation is evolutionary and occurs in the context of climatic, economic, tech- nological, social, and political forces that are difficult to isolate, and most adaptation practices serve multiple purposes (Smit and Skinner 2002). Recent studies have a tendency to focus on financial, technical and institutional criteria in order to evaluate the adaptive capacity (Haddad 2005). One factor has almost been entirely omitted by a majority of researchers: Perception. How can one adapt to climate change in an adequate way if he does not perceive the current and future climate change as a reality? It is reasonable to argue that the first step towards adaptation is the perception of the problem.

Boko et al. (2007) gave general examples of adaptation options in Africa that enhance citizen's social and economic resilience. Whether the extent of adaptation is adequate for current climate changes and predicted future climate regimes is the big concern. However, research on the adaptation of small-scale farmers in Nigeria has often occurred in the absence of knowledge of rural farmers' perception about climate change, its causes and impact, as well as existing adaptation responses. Because prevailing ideas about perception are vague, conducting focused research on effective adaptation practices and formulating appropriate policies and programmes for implementing new practices is difficult.

A fundamental issue surrounding perception studies in climate change research is methodology. Previous researches have focussed on analysing perception as dependent variables that were analysed separately using either descriptive statistics, probit or logit model. Social scientists have found that public risk perceptions strongly influence the way people respond to hazards. Public perception is critical because it is a key component of the socio-political context within which policy makers operate. Public perception can fundamentally compel or constrain political, economic and social action to address particular risks.

Human responses to environmental issues have been broadly categorised as cognitive (related to knowledge and understanding), affective (related to feelings, attitudes, and emotions), behavioural (related to changes in behaviour of the viewer), and physiological (biological or physical effects on the observer's body) (Zube et al. 1982).

Perception determines the social mental picture of climate change. But a number of other variables like socio-demographic and socio-eco- 
nomic factors or ideological orientations influence perception and the mental picture of climate change (Stedman 2004; Sjöberg 1995). Grothmann and Patt (2005) criticize that research is too much focused on "financial, technical, or institutional constraints" of adaptive capacity. Although they agreed that systems with limited economic resources, low levels of technology, poor information, unstable or weak institutions, and inequitable empowerment and access to resources are limited when it comes to adaptation.

However, perception decides over resource allocation. Without perceiving the risk adequately, all other determents seem meaningless. They therefore saw perception as a precondition for adaptation. They tested economical and technical adaptation of US farmers to climate change, and showed that perception was a dominating factor among all other kinds of variables. One reason why risk perception should be considered as meaningful for adaptation to climate change is the direct correlation with behaviour.

Peters (1997) opined that perception is important because a misconception of a risk has undesirable consequences. Misconceptions can lead to maladaptation, which increase the costs of climate change. Indeed, while a low perception of the risk could lead to an underestimation of a risk, a high perception of a risk could maybe result in exaggerated measures. Both extremes have negative consequences.

Slovic (1987) indicated that individuals form intuitive judgments about potential risk hazards and these judgments are commonly known as one's risk perceptions. According to Raden-Fessenden and Heath (1987), people base their perceptions upon their personal experiences, knowledge and character.

\section{MATERIAL AND METHODS}

\section{Area of the Study}

The study was carried out in rural farming communities in Benue, Nasarawa and Plateau States (Table 1), which are the focal states for the SLISSFAN project. These states are located in the North Central region of Nigeria and extends roughly from latitude $6^{0} 50^{\prime} \mathrm{N}$ to $9^{\circ} 30^{\prime} \mathrm{N}$ of the Equator and longitude $7^{0} 30^{\prime} \mathrm{E}$ to $10^{\circ} 00^{\prime} \mathrm{E}$ of the Prime Meridian. This area is largely located in the savannah of Nigeria with its northern edge lying on the border of the Sahel and its southern edge lying on the border of the rain forest of Nigeria. It is an ecological transition zone between the arid north and the moist south with temperature fluctuating between $18^{\circ} \mathrm{C}-37^{\circ} \mathrm{C}$ in the year and rainfall of $1000 \mathrm{~mm}$ to $1500 \mathrm{~mm}$ annually (Areola et al. 1999). Nasarawa and Benue States are located in the Niger-Benue trough and Plateau State on the Jos Plateau.

The main occupation of the people is predominantly rain-fed agriculture. This area is the nation's acclaimed food basket because of its rich agricultural produce which includes yams, rice, beans, cassava, maize, soybeans, sorghum, millet and cocoyam. Its ecology allows crops characteristic of its surrounding savannah region to the north and forest region to the south to be cultivated there. The soil and climatic conditions in parts of the area also favours the production of exotic crops like Irish potatoes, grapes, wheat and barley. The area boasts of one of the longest stretches of river systems in the country with great potential for a viable fishing industry, dry season farming through irrigation and for an inland water highway. The vegetation of the southern parts of the area is characterized by forests, which yield trees for timber and provide a suitable habitat for rare animals.

\section{Sampling and Sample Size}

The sampling frame was the 6000 farmers in the Oxfam/European Commission sponsored SLISSFAN project in Benue, Nasarawa and Plateau States. Simple random sampling technique with proportionate representation was used to determine sample size. A total of 411 respondents were sampled in the order of 163 in Plateau, 138 in Nasarawa, and 110 in Benue States. From the sampling frame, sample units that are aged 40 years and above and has lived in the community within the last 30 years were purposively selected. This was done to sample only respondents that will be able to recall temperature and rainfall patterns in their communities.

The instrument for data collection was a structured questionnaire. The questionnaire was translated into the local languages by interviewers especially for the respondents that could neither read nor write. Further information was obtained through in-depth interview of selected respondents. In deciding the unit of analysis, the household always seemed the logical choice: in most studies of coping strategies the house- 
hold is taken as the unit of analysis because it is assumed that decisions about production, investment and consumption are primarily taken at the household level. The household head was however used as proxy for household for this study.

Thirty (30) years (1980-2009) monthly meteorological data of temperature (minimum and maximum in ${ }^{0} \mathrm{c}$ ) and rainfall (rainfall amount in $\mathrm{mm}$ and rainfall days) for the Makurdi Meteorological Station was obtained from the Nigeria Meteorological Agency (NIMET), and used as proxy for the study area. Focussed group discussions with the farmers and key informant interviews with SLISSFAN project staff and community leaders were carried out to explore the depth of the key issues in the study. Data collection took place in February and March, 2011.

\section{Data Analysis Procedures}

The time series was used to analyse trends in temperature and rainfall. Linear regression trend lines were plotted using Microsoft Excel statistical tools and estimation of changes was determined. Linear regression focuses on the conditional probability distribution of $y$ given $x$. If the goal is prediction, or forecasting, linear regression can be used to fit a predictive model to an observed data set of $y$ and $x$ values. After developing such a model, if an additional value of $x$ is then given without its accompanying value of $y$, the fitted model can be used to make a prediction of the value of $y$.
Pearson Product Moment Correlation (PPMC) was also used. PPMC considers the relationship between two sets of variables X (independent) and Y (dependent). The computational formula, $r$ is given as:

$$
r=\frac{n \Sigma X Y-(\Sigma X)(\Sigma Y)}{\left[N \Sigma X^{2}-(\Sigma X)^{2}\right]-\left[N \Sigma Y^{2}-(\Sigma Y)^{2}\right]}
$$

Where $r=$ Pearson Correlation Coefficient between $\mathrm{X}$ and $\mathrm{Y}$; $\Sigma \mathrm{X}=$ Sum of the data in $\mathrm{X}$ distribution; $\Sigma Y=$ Sum of the data in Y distribution; $\Sigma X Y=$ Sum of the product of $X$ and $Y ; \Sigma X^{2}=$ Sum of the squared $\mathrm{X} ; \Sigma \mathrm{Y}^{2}=$ Sum of the squared $\mathrm{Y}$; $(\Sigma X Y)^{2}=$ Squared of sum of $X ;(\Sigma Y)^{2}=$ Squared of sum of $Y$; $n=$ Number of pairs of the measurement.

The $\mathrm{r}-$ value at the most can range from -1 to +1 : Value from \pm 0.0 to \pm 0.20 is a negligible relationship, \pm 0.21 to \pm 0.40 is a low relationship, \pm 0.41 to \pm 0.60 is a moderate relationship, \pm 0.61 to \pm 0.80 is a substantial relationship, \pm 0.81 to \pm 0.99 is a very high relationship, while an r value of \pm 1 is a perfect relationship.

\section{RESULTS AND DISCUSSION}

\section{Perception of Temperature and Rainfall}

As presented in Table 2, majority (71.9\%) of the farmers perceived an increase in air temperature while $41.4 \%$ perceived a decrease. Farmers who did not perceive any difference in air temperature were $4.4 \%$ and another $3.4 \%$ could not say if there have been changes in air temperature or not.

Table 1: Distribution of communities and Local Governments in the study area

\begin{tabular}{|c|c|c|c|c|}
\hline State & Local Government & Communities & $\begin{array}{l}\text { No. of commu- } \\
\text { nities }\end{array}$ & $\begin{array}{l}\text { No. of farm } \\
\text { households }\end{array}$ \\
\hline Plateau & $\begin{array}{l}\text { Bokkos } \\
\text { Mangu }\end{array}$ & $\begin{array}{l}\text { Kawel, Mbar, Makada, Wumat, } \\
\text { Maihakoringol, Folloh, Fagin, Foffai, } \\
\text { Bokkos and Kunet } \\
\text { Kerang, Ampang West, Panyam, } \\
\text { Bwonpe, Kopal, Gohotkung, Konbring, } \\
\text { Kinat, Tyop and Chanso }\end{array}$ & 20 & 2400 \\
\hline Benue & $\begin{array}{l}\text { Guma } \\
\text { Vandeikya } \\
\text { Buruku } \\
\text { Gboko }\end{array}$ & $\begin{array}{l}\text { Agasha } \\
\text { Mbaduku, Mbayongo } \\
\text { Tyowanye } \\
\text { Utabar }\end{array}$ & 5 & 1600 \\
\hline Nasarawa & $\begin{array}{l}\text { Obi } \\
\text { Lafia } \\
\text { Nasarawa Eggon }\end{array}$ & $\begin{array}{l}\text { Ikposogye, Musha, Tudu Adabu } \\
\text { Kirayi, Assakio, Rafin kudi } \\
\text { Ahenta, Ogbagi, Gbamze West }\end{array}$ & 9 & 2000 \\
\hline 3 & 9 & & 34 & 6000 \\
\hline
\end{tabular}


Table 2 also showed that $50.8 \%$ of the farmers perceived an increase in rainfall amount and $41.4 \%$ perceived a decrease in past thirty years. Farmers who did not perceive any difference in rainfall amount were $4.4 \%$ and $3.4 \%$ could not say if there have been changes in rainfall amount or not.

Table 3 indicated that $83.7 \%$ of the farmers perceived that rainfall pattern is unpredictable by the year and $10.9 \%$ are of the perception that rainfall pattern is predictable by the year within the last 30 years.

Temperature and rainfall are the two climatic variables that influence farming the most in the study area. In farming, the amount of rainfall is important and is an indicator of long term changes in the climate system. However, of more importance to farmers is the pattern of the rainfall. If the rain falls in the right amount and then it ceases for a long period before the next rain, the long dry spell can be devastating to farmers. If however the rain falls in small amount but at the expected time and spread over the period of planting, it is a good season for farmers.

Table 2: Distribution of respondents by perception of temperature and rainfall amount within the last 30 years

\begin{tabular}{lrr}
\hline Perception & Frequency & $\begin{array}{r}\text { Percentage } \\
(\%)\end{array}$ \\
\hline Air Temperature & & 71.9 \\
Increased & 295 & 71.9 \\
Decreased & 91 & 22.1 \\
Stayed same & 15 & 3.6 \\
Don't know & 10 & 2.4 \\
Total & 411 & 100.0 \\
Rainfall Amount & & \\
Increased & 209 & 50.8 \\
Decreased & 170 & 41.4 \\
Stayed same & 18 & 4.4 \\
Don't know & 14 & 3.4 \\
\hline Total & 411 & 100.0 \\
\hline
\end{tabular}

Source: Field Survey 2011

Table 3: Distribution of respondents by perception of rainfall predictability by within the last 30 years

\begin{tabular}{lcr}
\hline $\begin{array}{l}\text { Rainfall pattern } \\
\text { predictable by the year }\end{array}$ & Frequency & $\begin{array}{r}\text { Percentage } \\
(\%)\end{array}$ \\
\hline Agree & 45 & 10.9 \\
Neutral & 22 & 5.4 \\
Disagree & 344 & 83.7 \\
\hline Total & 411 & 100.0 \\
\hline Source: Field Survey 2011 &
\end{tabular}

Source: Field Survey 2011

\section{Analysis of Temperature and Rainfall Data}

The farmers' perception was compared with meteorological records of temperature and rainfall of the study area. The result showed an increasing trend. During the 30 years period, the minimum temperature has risen by $0.1^{\circ} \mathrm{C},\left(\mathrm{y}^{0}=\right.$ $22.4+0.003 \mathrm{x}$ ) fluctuating between the lowest of $21.6^{\circ} \mathrm{C}$ in 2007 and the highest of $23.4^{\circ} \mathrm{C}$ in 2004 and 2005 , with Mean of $22.4^{\circ} \mathrm{C}$ and Standard Deviation of 0.22 . The seven highest minimum temperature years recorded within the period has been within the last 12 years. It was also revealed that an increasing trend. During the 30 years period, the maximum temperature has risen by $0.49^{\circ} \mathrm{C}\left(\mathrm{y}^{0}=33.43+0.016 \mathrm{x}\right)$, with the lowest in $2007\left(32.7^{\circ} \mathrm{C}\right)$ and highest in $1998\left(34.2^{\circ} \mathrm{C}\right)$, with Mean of $33.4^{\circ} \mathrm{C}$ and Standard Deviation of 0.33 . These are indicators that Nigeria will be hard hit by global warming in the nearest future.

Odjugo (2010) had shown that the temperature trend in Nigerian since 1901 shows increasing pattern. The increase was gradual until the late 1960s and this gave way to a sharp rise in air temperatures from the early 1970s, which continued till date. The Mean air temperature in $\mathrm{Ni}$ geria between 1901 and 2005 was $26.6^{\circ} \mathrm{C}$ while the temperature increase for the 105 years was $1.7^{\circ} \mathrm{C}$. This is higher than the global Mean temperature increase of $0.74^{\circ} \mathrm{C}$ recorded since 1860 when actual scientific temperature measurement started (Spore 2008; Boko et al. 2007). Should this trend continue unabated, Odjugo (2010) predicted that Nigeria may experience between the middle $\left(2.5^{\circ} \mathrm{C}\right)$ and high $\left(4.5^{\circ} \mathrm{C}\right)$ risk temperature increase by the year 2100 .

Given that $71.9 \%$ of farmers in the study perceived an increase in air temperature, it can be inferred that the farmers' perception of temperature is in accordance with meteorological records in the region.

The total annual rainfall for Makurdi meteorological station for the period 1980 to 2009 has an increasing trend $\left(y^{0}=95.7+1.54 x\right)$. Over the 30 years period, total annual rainfall amount has increased by $46.2 \mathrm{~mm}$. The mean total annual rainfall amount is $1177.2 \mathrm{~mm}$, with lowest rainfall of $770.4 \mathrm{~mm}$ (2003) and highest of $1772.4 \mathrm{~mm}$ (1992). The wet season average rainfall amount in 5 years period revealed a consistent drop in rainfall amount in the month of July. Between 1980 and 1984, average rainfall was highest in July and by 2005 to 2009 it was lowest. Also, there 
has been an increase in average rainfall trend in August $(8.33 \mathrm{~mm} / 30$ years) and a decrease in July $(-473.0 \mathrm{~mm} / 30$ years $)$ and September $(-2.32 \mathrm{~mm} / 30$ years). This scenario is contrary to previously experienced and documented rainfall pattern in Nigeria prior to the 1970 s, in which there is double rainfall maxima in June and September with a break in August (FME 2003) and supports Odjugo (2005) and Odjugo (2007) which indicated that the short dry period during the raining season is gradually moving from August to July. These are major disruptions in the climatic patterns of Nigeria showing evidences of a changing climate. The shifts in rainfall pattern are becoming a worrisome development, as among other things farmers find it difficult to time their farming operations.

\section{Correlation between Age, Sex, Education and Household Size and Perception of Climate Change Indicators}

The variable pairs indicated in Table 4 represent the significant correlation the hypothesized demographic characteristics has on perception of climate change indicators.

Age of household head was found to impact significantly on the perception that the amount of water flow in streams is decreasing. The implication of this is that a farmer who perceives a decrease in amount of water flow in streams might have perceived differently if his/her age were different, all other things being equal. This may be because with age, farmers are better able to identify receding shoreline of streams and rivers and its decreasing depth over the years. Because seasons (dry or rainy) affect these variables of streams and rivers in its circles, it may require experience based on age to identify that the streams/rivers do not return to their previous levels and boundaries after each circle.

Age of household head was found to also impact significantly on the perception that there are changes in tree flowering and fruiting time. Unlike crops, trees require several seasons of growth before flowering and fruiting begins in circles. The interpretation of this is that farmers who perceive a change in tree flowering and fruiting time might have had a different perception if they were older or younger, other things being equal.

Sex of household head had significant impact on the perception that incidence of drought is increasing. Drought-like conditions with its resultant scarcity of water and dryness affects both farming and domestic activities adversely. The interpretation of this is that under a given condition, a farmer who perceives an increase in incidence in drought might have perceived otherwise if his/her sex was different. Perception that amount of water flow in streams/rivers is decreasing is significantly impacted by sex of household head. It can thus be inferred that a male farmers who perceive a decrease in amount of water flowing in streams might have perceived differently if he were a female, all other conditions being equal. While women are likely to use the streams for washing clothes and fetching water, men are more likely to lead their animals there for drinks and for activities such a swimming.

Sex of household head had significant impact on their perception that there is occurrence of extinct and shifting plant species. A key informant in Benue State confirmed that the presence of weeds not native to some communities in Vandeikya local government has been sighted and reported. By implication, farmers who perceive extinct or shifting plant species might have had a different perception if their sex was different, all thing being equal. Sex of household head also had significant impact on the perception that fuel wood is getting scarce by the year. Collection of fuel wood is the exclusive duty of women in rural area.

The implication of this finding is that a farmer who perceives that fuel wood is getting scarce by the year might perceive otherwise if his/her sex were different, given that all other things are equal. The perception that climate change affects women more than men is impacted significantly be the sex of household head. Thus, a female household head who perceived that climate change affects women more than men might have perceived otherwise if she were a male, all things being equal.

Education of household head was found to impact significantly on the perception that climate change is happening everywhere in the world. This may be due to the fact that education brings about exposure to areas beyond ones immediate locale. Thus, the implication of the finding is that a farmer who perceives that climate change is happening everywhere in the world might have a different perception if his/ her level of education was different, all things being equal. 
Similarly, the perception that climate change affects women more than men is significantly impacted by education of household head. Therefore, a farmer who has a higher level of education considers his education in deciding whether climate change affects women more than men. For instance, a farmer who has a high level of education will have a different perception if he was to have a low level of education. Studies by Norris and Batie (1987), Igoden et al. (1990) and Lin (1991), associated higher level of education with access to information on improved technologies and thus better perception.

Household size had significant impact of the perception that amount of water flow in streams is decreasing. By interpretation, a larger family's perception of the amount of water flow in streams would be different from that of a smaller family, all things being equal. Household size is associated with farm labour availability and will also likely determine how many people that will go to the stream to fetch water and the rate at which a household use water.

The perception that fuel wood is getting scarce was significantly impacted by the size of household. Larger household will utilize more fuel wood for domestic purposes and by interpretation; a household's perception of fuel wood scarcity will be different if the size of the household was different, all things being equal.

Household size also had significant impact of the perception that climate change is causing conflict for resource control in the community. Household size is also linked with social ties and network in a community, and Isham (2002) stated that social capital plays a significant role in information exchange, which itself influences perception. The quantity of a particular resource available in a place, the size of the population as well as the heterogeneity of the population is causative factor for conflict. The finding thus imply that all things being equal, a household's perception of climate change causing conflict for resource control will be different if it's size was different.

\section{CONCLUSION}

The study concluded that the climate in the North Central region of Nigeria is experiencing an increasing trend in temperature as well as rainfall amount, but rainfall is unpredictable and deviating from previously known pattern. Rural farmers' perceptions of temperature and rainfall are validated by meteorological records. The demographic attributes of farmers have influence on their perception to climate change. The sex of rural farmers has influence on their perception of climate change, age, education and household size, together with sex, is correlated the perception of climate change impact on some social, biophysical and eco-system functions.

\section{RECOMMENDATIONS}

Based on these findings, it was recommended that researches and government policies to address climate change and agriculture should

Table 4: Significant correlation between selected demographic characteristics of small scale farmers and their perception of climate change indicators

\begin{tabular}{|c|c|c|}
\hline Variable pairs & $\begin{array}{c}\text { Pearson } \\
\text { correlation }\end{array}$ & $\begin{array}{l}\text { Sig. }(2 \\
\text { Tailed) }\end{array}$ \\
\hline Age and amount of water flow in streams decreasing & $-.114\left(^{*}\right)$ & .026 \\
\hline Age and changes in trees flowering and fruiting time & $-.113^{(*)}$ & .026 \\
\hline Sex and incidence of drought is increasing & $.113\left(^{*}\right)$ & .027 \\
\hline Sex and amount of water flow in streams decreasing & $.100\left(^{*}\right)$ & .049 \\
\hline Sex and extinct/shifting plant species & $.161\left({ }^{* * *}\right)$ & .002 \\
\hline Sex and fuel wood is getting scarce by the year & $.110\left(^{*}\right)$ & .033 \\
\hline Sex and climate change affects women more than men & $.236\left(^{* * *}\right)$ & .000 \\
\hline Education and climate change is happening everywhere in the world & $.100\left(^{*}\right)$ & .048 \\
\hline Education and climate change affects women more than men & $.114\left(^{*}\right)$ & .027 \\
\hline Household size and amount of water flow in streams decreasing & $-.110\left(^{*}\right)$ & .033 \\
\hline Household size and fuel wood is getting scarce by the year & $-.135\left(^{* *}\right)$ & .009 \\
\hline $\begin{array}{l}\text { Household size and climate change is causing conflicts for resource } \\
\text { control in the community }\end{array}$ & $-.113\left(^{*}\right)$ & .030 \\
\hline
\end{tabular}

** Correlation is significant at the 0.01 level (2-tailed)

* Correlation is significant at the 0.05 level (2-tailed)

Source: Computer Print-out 2011 
take into cognisance the demographic attributes of farmers and farming communities. Climate change awareness is still very much needed among rural farmers, and in doing so, data should be disaggregated and disseminated at the community level, putting into consideration demographic factors, especially gender issues.

\section{REFERENCES}

Ajayi S 2009. Impact of Climate Change on Food Security in Nigeria. Agricultural Show Seminar, Tudun Wada, Karu LGA, Nasarawa State.

Areola O, Mamman, M 1999. Geography for SSCE and $J M E$. Ibadan: University Press.

Boko M, Niang I, Nyong A, Vogel C, Githeko A, Medan M, Osman-Elasha B, Tabo R, Yanda P 2007. Climate change 2007 - Impacts, adaptation and vulnerability in Africa. In: ML Parry, OF Canziani, JP Palutikof, PJ van der Linden, CE Hanson (Eds.): Contribution of Working Group II to the Fourth Assessment Report of the Intergovernmental Panel on Climate Change. Cambridge, UK: Cambridge University Press, pp. 433-467.

Denton F 2002. Climate change vulnerability, impacts, and adaptation: Why does gender matter? Gender and Development, 10(2): 10-20.

Federal Ministry of Environment (FME) 2003. Nigeria's First National Communication under the United Nations Framework Convention on Climate Change. Abuja, Nigeria.

Grotmann T, Patt A 2000. Adaptive capacity and human cognition: The process of individual adaptation to climate change. Global Environmental Change, 15(3): 199-213.

Gustafson P 1998. Gender differences in risk perception: Theoretical and methodological perspectives. Risk Analysis, 18(6): 805-811.

Haddad B 2005. Ranking the adaptive capacity of nations to climate change when socio-political goals are explicit. Global Environmental Change, 15: $165-176$

Hemmati M 2005. Gender and Climate Change in the North: Issues Entry Points and Strategies for the Post-2012 Process and Beyond, Berlin: Genanet / Focal Point Gender Justice and Sustainability .

Igoden C, Ohoji P, Ekpare J 1990. Factors associated with the adoption of recommended practices for maize production in the Lake Basin of Nigeria. Agricultural Administration and Extension, 29(2): 149-156.

Isham J 2002. The effect of social capital on fertiliser adoption: Evidence from rural Tanzania. Journal of African Economies, 11: 39-60.

Lin J 1991 Education and innovation adoption in agriculture: Evidence from hybrid rice in China. American Journal of Agricultural Economics, 73(3): $713-723$

Maddison D 2006 The Perception of and Adaptation to Climate Change in Africa. CEEPA Discussion Paper No.10. Centre for Environmental Economics and Policy in Africa. Pretoria, South Africa: University of Pretoria.

Mapfumo P 2008. Farmers' Perception Leads to Experimentation and Learning. LEISA Magazine, 24. December 2008
Microsoft Encarta 2007. Microsoft Corporation.

Nhemachena C, Hassan R 2007 Micro-Level Analysis of Farmers' Adaptation to Climate Change in Southern Africa. IFPRI Discussion Paper No. 00714. Washington DC: International Food Policy Research Institute.

Nigerian Environmental Study/Action Team (NEST) 2003. Climate Change in Nigeria: A Communication Guide for Reporters and Educators. Ibadan: NEST, Ibadan, pp. 5-16.

Norris E, Batie S 1987. Virginia farmers' soil conservation decisions: An application of Tobit Analysis. Southern Journal of Agricultural Economics, 19(1): 89-97.

Odjugo PAO 2010. General overview of climate change impacts in Nigeria. Journal of Human Ecology, 29(1): 47-55.

Odjugo PAO 2007. The impact of climate change on water resources: Global and regional analysis. The Indonesian Journal of Geography, 39: 23-41.

Odjugo PAO 2005. An analysis of rainfall pattern in Nigeria. Global Journal of Environmental Science, 4(2): 139-145

Ogbo A, Lauretta NE, Ukpere W 2013. Risk management and challenges of climate change in Nigeria. J Hum Ecol, 41(3): 221-235.

Peters G 1997. Risk analysis. Technology, Law and Insurance, 2: 97-110

Raden-Fessenden F, Heath J 1987. Providing risk information in communities: Factors influencing what is heard and accepted. Science, Technology and Human Values, 12(3-4): 94-101.

Sjöberg L 1995. Explaining Risk Perception: An Empirical and Quantitative Evaluation of Cultural Theory Risk Research Reports. Stockholm: Center for Risk Research, Stockholm School of Economics.

Skutsch M 2002. Protocols, treaties and action: The 'climate change process' through gender spectacles. Gender and Development, 10(2): 30-39.

Slovic P 1987. Perception of risk. Science, 236: 280285

Smit B, Skinner M 2002. Adaptation options in agriculture to climate change: A typology. Mitigation and Adaptation Strategies for Global Change, 7: 85-114.

SPORE 2008. Climate Change. Spore Special Issue. August, 2008

StataCorp 2003. Stata Base Reference Manual. Volume 4, G-M, release 8. Collage Station, TX: Stata Corporation.

Stedman R 2004. Risk and climate change: Perceptions of key policy actors in Canada. Risk Analysis, 24: 1395-1406

Tenge J, De Graaff, Hella JP 2004. Social and economic factors affecting the adoption of soil and water conservation in West Usambara highlands, Tanzania. Land Degradation and Development, 15(2): 99-114

Van De Ven WP, Van Praag BM 1981. The demand for deductibles in private health insurance: A Probit Model with sample selection. Journal of Econometrics, 17: 229-252.

Weber E, Blais AR, Betz N 2002. A domain-specific risk-attitude scale: Measuring risk perceptions and risk behaviours. Journal of Behavioural Decision Making, 5: 1-28.

Zube EH, Sell JL, Taylor, JG 1982. Landscape perception: Research, application, and theory. Landsc Plann, 9: 1-33. 